\title{
nature
}

7 April 2005 Volume 434 Issue no 7034

\section{Uncomfortable truths}

A thorough investigation of German scientists' actions under the Nazi regime reveals a more complex and ambiguous story than that implanted in the public mind at the end of the Second World War.

$\mathrm{T}$ he inhumanity of some of the research carried out in Germany during the Third Reich is well known, and universally abhorred. The work of Josef Mengele, the young doctor who conducted deadly genetics experiments on inmates of Auschwitz, is perhaps the most notorious example of these appalling crimes.

For decades after the Second World War, the prevailing view of how scientists interacted with the Nazi regime was fixated on such cases of dramatic criminality. According to this view, science during the Nazi era was contaminated by a few, very rotten apples. This version of history also held that these rotten apples were engaged in 'pseudoscience' - low-quality research whose results were meaningless; that the Nazis held 'real' science in low esteem, so that the main body of scientists simply trod water for the duration; and that most of those who did work to further the aims of the regime did so under duress.

This conventional wisdom was broadly framed at the Nuremberg trials, which condemned the heinous crimes of high-ranking Nazis, but did not enquire into the behaviour of less notorious individuals, including rank-and-file scientists.

This account suited both the winners and losers of the war. By eliminating the worst offenders, justice was seen to be done. Experienced scientists and research managers were left alone to rebuild the science infrastructure of the destroyed country. The victorious Allies needed what was then West Germany to function as a strong but peaceful country, as a bastion against the communist threat to the East. And science was an integral part of that.

\section{Second take}

More recently, science historians have begun to question the rottenapple/pseudoscience view, in parallel with a broader historical reassessment of this calamitous period in German history. The ambiguity and complexity of individual behaviour and motivation during the war have been reflected not just in academia, but also in plays such as Copenhagen, and a flurry of films including Taking Sides, Sophie Scholl and Downfall (Der Untergang).

Germany's main scientific institutions have been moved to reassess their own twentieth-century histories. For example, the university grant-giving agency, the DFG, has investigated its funding of research that supported Nazi policies. But it is the Max Planck Society (MPS), which administers 80 research institutes in Germany, that has taken the lead in exposing its own past to unflinching scrutiny.

In 1999, Hubert Markl, then MPS president, launched a six-year, $€ 4$-million (US\$5-million) programme, conducted by independent science historians, to systematically analyse the role of the society then known as the Kaiser Wilhelm Society — and its scientists in supporting the Nazi regime's policies. The programme ended last month, and the results of its many projects confirm the superficiality of the accepted view.

The MPS has found that a large part of the most criminal research conducted was not 'pseudoscience' - in fact, it followed conventional scientific methods and was at the cutting edge of research at the time. It has also demonstrated that the Nazis held basic research in high esteem, increasing funding for it during the war years without requiring scientists to join the Nazi Party. And it found that, far from being subjected to force, many scientists voluntarily oriented their work to fit the regime's policies - as a way of getting money and of exploiting the new resources that Nazi policies made available through, for example, the invasion of other countries. Most researchers, it turns out, seem to have regarded the regime not as a threat, but as an opportunity for their research ambitions.

\section{Lessons for the future}

It has taken more than 50 years for such a serious, dispassionate reanalysis to become possible, at least in Germany - for both psychological and practical reasons. First, a generation of academics is retiring, and their successors need a clear path, unburdened by the legacy of the Third Reich and the pressures to rebuild Germany after the war. Second, important Russian archives became available to Western historians only after the end of the cold war.

The programme's final conference, held last month in Berlin, made clear the productivity of the endeavour. A thick dossier of publications is also freely available on the website of the Max Planck Institute for the History of Science, which hosted the independent group in Berlin (www.mpiwg-berlin.mpg.de/ KWG/engl.htm). The dossier portrays individuals who clearly overstepped the ethical line, such as plant geneticist Hans Stubbe, who collaborated with the SS to get hold of valuable Russian plant collections after the invasion of Russia.

It reveals even more about a large ethical grey area. Researchers at the Kaiser Wilhelm Institute for Metal Research in Stuttgart, for example, voluntarily came up with many projects to improve the performance of existing weapons. And it bears out accusations made against Adolf Butenandt, the Nobel-prizewinning biochemist who was president of the MPS during 1960-72 (see Nature 393, 109-111; 1998). It seems that Butenandt must have known that Auschwitz blood samples were being handled at his Institute for Biochemistry in Berlin.

The exercise has also brought historians to the point where they can formulate new questions, moving on from the identification and condemnation of individuals to the more general issue of how the scientific community interacted with the regime, to better understand the history of that time and to learn from it.

In the 1930s and early 1940s, it seemed to those living under fascist flags that fascism was immortal. Until 1942, few Germans - or Italians, for that matter - imagined that the ruling regimes would be overthrown, or be replaced by a democratic system that would judge many of the actions they considered loyal, patriotic, or simply getting on with their job, as unacceptable support for a criminal regime.

The MPS is to be praised for its courage in opening itself up so completely to scrutiny, and for funding the investigation at a time when its own finances are being severely curtailed. The work has shed light on the behaviour of scientists as individuals and as groups. And it serves as a timely reminder of the need for strict ethical limits to be defined, and adhered to.

The action has been positive, and in its grim way liberating, for German scientists. "Those who are fixated only on the past will move blindly into the future," Markl told the programme's final conference, "as will those who are concerned only with the present." 